\title{
Alexander Fleming (1881-1955): Discoverer of penicillin
}

\author{
Siang Yong $\operatorname{Tan}^{1}$, MD, JD, Yvonne Tatsumura ${ }^{2}$, MA, MD
}

"I did not invent penicillin. Nature did that. I only discovered it by accident."

$\Lambda$ lexander Fleming was a Scottish physician-scientist who was recognised for discovering penicillin. The simple discovery and use of the antibiotic agent has saved millions of lives, and earned Fleming - together with Howard Florey and Ernst Chain, who devised methods for the large-scale isolation and production of penicillin - the 1945 Nobel Prize in Physiology/Medicine.

BEG I N N INGS On August 6, 1881, Alexander Fleming was born to Hugh Fleming and Grace Stirling Morton in Lochfield Farm, Scotland. Initially schooled in Scotland, Fleming eventually moved to London with three brothers and a sister, and completed his youth education at the Regent Street Polytechnic. He did not enter medical school immediately after; instead, he worked in a shipping office for four years. When his uncle John died, he willed equal shares of his estate to his siblings, nieces and nephews, and Fleming was able to use his share to pursue a medical education. In 1906, he graduated with distinction from St Mary's Medical School at London University.

FORTUNATE CHOICES Fleming did not intend to begin a career in research. While serving as a private in the London Scottish Regiment of the Territorial Army, he became a recognised marksman. Wishing to keep Fleming in St Mary's to join its rifle club, the club's captain convinced him to pursue a career in research rather than in surgery, as the latter choice would require him to leave the school. The captain introduced him to Sir Almroth Wright, a keen club member and a pioneer in immunology and vaccine research, who agreed to take Fleming under his wing. It was with this research group that Fleming stayed throughout his entire career.

When World War I broke out, Fleming served in the Army Medical Corps as a captain. During this time, he observed the death of many of his fellow soldiers, not always from wounds inflicted in battle, but from the ensuing infection that could not be controlled. The primary means to combat infection was antiseptics, which frequently did more harm than good. In an article he wrote during this time, Fleming discussed the presence of anaerobic bacteria in deep wounds, which proliferated despite antiseptics. Initially, his research was not accepted, but Fleming continued undaunted and in 1922, he discovered lysozyme, an enzyme with weak antibacterial properties. History tells us that, while infected with a cold, Fleming transferred some of his nasopharyngeal mucus onto a Petri dish. Not known for fastidious laboratory organisation, he placed the dish among the clutter at his desk and left it there, forgotten, for two weeks. In that time, numerous colonies of bacteria grew and proliferated. However, the area where the mucus had been inoculated remained clear. Upon further investigation, Fleming discovered the presence of a substance in the mucus that inhibited bacterial growth and he named it lysozyme. He also discovered lysozyme in tears, saliva, skin, hair and fingernails. He was soon able to isolate larger amounts of lysozyme from egg white, but in subsequent experiments found that this enzyme was effective against only a small number of non-harmful bacteria. Nevertheless, this would lay the groundwork for Fleming's next great discovery.

'MOULD JUICE' In 1928, Fleming began a series of experiments involving the common staphylococcal bacteria. An uncovered Petri dish sitting next to an open window became contaminated with mould spores. Fleming observed that the bacteria in proximity to the mould colonies were dying, as evidenced by the dissolving and clearing of the surrounding agar gel. He was able to isolate the mould and identified it as a member of the Penicillium genus. He found it to be effective against all Gram-positive pathogens, which are responsible for diseases such as scarlet fever, pneumonia, gonorrhoea, meningitis and diphtheria. He discerned that it was not the mould itself but some 'juice' it had produced that had killed the bacteria. He named the 'mould juice' penicillin. Later, he would say: "When I woke up just after dawn on September 28, 1928, I certainly didn't plan to revolutionize all medicine by discovering the world's first antibiotic, or bacteria killer. But I suppose that was exactly what I did."

Although Fleming published the discovery of penicillin in the British Journal of Experimental Pathology in 1929, the scientific community greeted his work with little initial enthusiasm. Additionally, Fleming found it difficult to isolate this precious 'mould juice' in large quantities. It was not until 1940, just as he was contemplating retirement, that two scientists, Howard Florey and Ernst Chain, became interested in penicillin. In time, they were able to mass-produce it for use during World War II. 
Fleming received many awards for his achievements. In 1928, he became Professor of Bacteriology at St Mary's. He was elected a Fellow of the Royal Society in 1943 and elevated to the level of Emeritus Professor of Bacteriology at the University of London in 1948. A recipient of some thirty honorary degrees, in 1945, he won the most prestigious award, the Nobel Prize in Physiology/ Medicine. He was made a Knight Bachelor by King George VI in 1944 and a Knight Grand Cross of the Order of Alfonso X the Wise in 1948. Time Magazine named Fleming one of the 100 most important people of the 20th century.

PERSONAL LIFE Fleming was a quiet, patient and modest gentleman, not given to displays of emotion, with a natural shyness that made him avoid accolades and attention. He could be silent to the point of being inscrutable, making it difficult even for his wife and closest friends to gauge his moods and desires. He was occasionally brusque and aloof, yet charming and gentle among friends and loved ones. In 1915, he married an Irish-born nurse named Sarah Marion McElroy, who went by the nickname Sareen. After nine years of marriage, they had a son named Robert Fleming, who went on to become a general practitioner. Sareen died after 34 years of marriage, and her death affected Fleming profoundly. He subsequently buried himself in his work, spending longer hours in his laboratory behind closed doors. A biographer wrote: "As if overnight, Fleming, with red-rimmed eyes and trembling hands, seemed to have become an old man." However, in 1953, Fleming remarried Dr Amalia Koutsouri-Vourekas in a Greek church in London.

On March 11, 1955, Alexander Fleming suddenly died of coronary thrombosis at home. He had been suffering from what he perceived to be gastric upset for some weeks. When his wife called their family physician regarding the onset of nausea on March 11, he reassured them that a house visit was not necessary. However, within minutes, he succumbed to the coronary event. His cremated ashes were placed in St Paul's Cathedral, and "[h]e died as he wished; quietly, without a gradual decline in physical or mental capacity, and even without inconveniencing his physician".

\section{BIBLIOGRAPHY}

- Alexander Fleming. Available at http://en.wikipedia.org/wiki/Alexander_ Fleming.

- Berger M. Famous Men of Modern Biology. New York: Thomas Y. Crowell Company, 1968.

- Fleming A. On the antibacterial action of cultures of a penicillium, with special reference to their use in the isolation of B. influenzae. 1929. Bull World Health Organ 2001; 79:780-90.

- Lechevalier HA, Solotorovsky M. Three Centuries of Microbiology. New York: Dover Publications Inc, 1974.

- Ludovici LJ. Fleming: Discoverer of Penicillin. London: The Scientific Book Club, 1952.

- MacFarlane G. Alexander Fleming. Cambridge: Harvard University Press, 1984.

- Maurois A. The Life of Sir Alexander Fleming: Discoverer of Penicillin. New York: E.P. Dutton \& Co, 1959.

- Nobel Lectures, Physiology or Medicine 1942-1962, Elsevier Publishing Company, Amsterdam, 1964. Available at: http://nobelprize.org/nobel_prizes/ medicine/laureates/1945/fleming-bio.html. Accessed February 11, 2008. 